\title{
ALK NM_004304.4:C.3512T>A
}

National Cancer Institute

\section{Source}

National Cancer Institute. ALK NM 004304.4:C.3512T>A. NCI Thesaurus. Code C133481.

A nucleotide substitution at position 3512 of the coding sequence of the ALK gene where thymine has been mutated to adenine. 